\title{
A novel method for DNA delivery into bacteria using cationic copolymers
}

\author{
V.V. de Souza ${ }^{1 \oplus}$, P.A.M. Vitale ${ }^{1 \oplus}$, F.H. Florenzano ${ }^{2 \oplus}$, R.K. Salinas ${ }^{1 \oplus}$, and I.M. Cuccovia ${ }^{1 \oplus}$ \\ ${ }^{1}$ Departamento de Bioquímica, Instituto de Química, Universidade de São Paulo, São Paulo, SP, Brasil \\ ${ }^{2}$ Departamento de Engenharia de Materiais, Escola de Engenharia de Lorena, Universidade de São Paulo, Lorena, SP, Brasil
}

\begin{abstract}
Amphiphilic copolymers have a wide variety of medical and biotechnological applications, including DNA transfection in eukaryotic cells. Still, no polymer-primed transfection of prokaryotic cells has been described. The reversible additionfragmentation chain transfer (RAFT) polymer synthesis technique and the reversible deactivation radical polymerization variants allow the design of polymers with well-controlled molar mass, morphology, and hydrophilicity/hydrophobicity ratios. RAFT was used to synthesize two amphiphilic copolymers containing different ratios of the amphiphilic poly[2-(dimethyl-amino) ethyl methacrylate] and the hydrophobic poly [methyl methacrylate]. These copolymers bound to pUC-19 DNA and successfully transfected non-competent Escherichia coli $\mathrm{DH} 5 \alpha$, with transformation efficiency in the range of $10^{3}$ colony-forming units per $\mu \mathrm{g}$ of plasmid DNA. These results demonstrate prokaryote transformation using polymers with controlled amphiphilic/hydrophobic ratios.
\end{abstract}

Key words: Gene delivery; Bacterial transformation; Copolymers; DMAEMA

\section{Introduction}

Amphiphilic copolymers self-assemble in water, forming various aggregates that exhibit a wide variety of technological applications $(1,2)$. Amphiphilic copolymers may respond to diverse stimuli such as temperature, $\mathrm{pH}$, or ions (3-6). Modulation of polymer solubility by $\mathrm{pH}$ and temperature provides an efficient way to control the delivery and release of trapped molecules $(7,8)$. Amphiphilic cationic copolymers bind to DNA, facilitating eukaryotic cell transformation, thereby constituting an alternative to viral DNA/RNA vectors $(9,10)$. Cationic polymers synthesized from 2(dimethyl-amino) ethyl methacrylate (DMAEMA) with different morphologies facilitate DNA delivery to eukaryotic cells but are cytotoxic (11-13). Other polymeric materials deliver DNA into eukaryotic cells, but a polymeric system capable of transfecting bacteria has not been described. Copolymer morphology and composition may be modulated to maximize gene delivery efficiency and, hopefully, minimize toxicity. Gradient or random copolymers of poly [DMAEMA] (PDMAEMA) with few polar units could have advantages over previous DMAEMA-based copolymers tested for DNA delivery (14). Systematic changes of copolymer molar and composition ratios may permit the design of better materials for DNA delivery, eventually with reduced toxicity (15).

Here, we synthesized positively charged polymeric materials as potential DNA vectors using synthetic methods, including free radical polymerization (FRP) $(16,17)$, reversible addition-fragmentation chain transfer polymerization (RAFT), and a reversible deactivation radical polymerization. Polymers consisting of PDMAEMA and poly (methyl methacrylate) (PMMA) obtained via FRP or RAFT bind DNA and efficiently promoted plasmid DNA transfer into Escherichia coli. These observations pave the way towards developing new synthetic materials based on PDMAEMAco-PMMA copolymers, with optimized properties to carry DNA into eukaryotic and prokaryotic cells (Figure 1).

\section{Material and Methods}

\section{Materials}

Methanol, n-hexane, acetone (analytical grade), and triethylamine (TEA) (HPLC grade) were from J.T. Baker (USA). Tetrahydrofuran (THF), deuterated chloroform $\left(\mathrm{CDCl}_{3}\right)$, methyl methacrylate (MMA, 99\%), and dimethyl 2-(aminoethyl) methacrylate (DMAEMA, 98\%) were from Sigma-Aldrich (USA) and their polymerization inhibitor, MEHQ, was removed using De-HiBit-200 (Polysciences, Inc., USA) macroreticular ion exchange resin. 2,2'-azobisisobutyronitrile (AIBN, 98\%), 1,1'-azobis(cyclohexane carbonitrile) (ACHN, 98\%), 2-cyano-2-propyl dodecyl trithiocarbonate (chain transfer agent, CTA), and buffers 


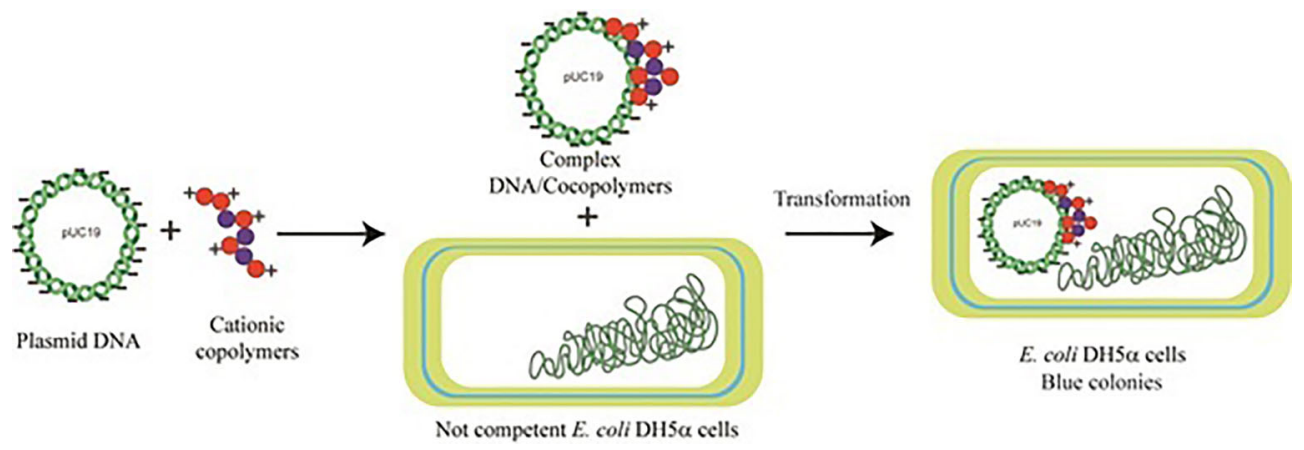

Figure 1. PDMAEMA-based cationic copolymers as novel carriers for DNA delivery into bacteria. Here we show that amphiphilic copolymers containing DMAEMA deliver DNA into $E$. coli cells opening the way to the development of new DNA delivery agents.

were from Sigma-Aldrich. $\mathrm{NaH}_{2} \mathrm{PO}_{4}$, boric acid, $\mathrm{HCl}$, and $\mathrm{NaOH}$ were from Merck (Germany). Isopropyl $\beta$-D-1thiogalactopyranoside (IPTG) and 5-bromo-4-chloro-3indolyl $\beta$-D-galactoside (X-Gal) were from Thermo Scientific (USA). Gel permeation chromatography (GPC) standard for average molar mass determination was Poly(methyl methacrylate) Standard ReadyCal Set, Mp $500-2,700,000$, from Sigma Aldrich.

\section{Chemical syntheses}

All syntheses were carried out under argon and constant stirring at $600 \mathrm{rpm}$. The growth of the polymer chains during synthesis was monitored by GPC analysis of reaction aliquots taken at increasing reaction times.

\section{Free radical polymerization}

PMMA-co-PDMAEMA was synthesized via FRP technique using $\mathrm{ACHN}$ as initiator. $\mathrm{PMMA}_{3}$-Co-PDMAEMA 26 (FRP): $5 \mathrm{~mL}$ (46.7 mmol/L) of MMA, $20 \mathrm{~mL}$ (118.7 mmol/L) of DMAEMA, and $0.289 \mathrm{~g}(1.18 \mathrm{mmol} / \mathrm{L})$ of $\mathrm{ACHN}$ were mixed in a reaction flask with $10 \mathrm{~mL}$ of 1,4-dioxane. The polymerization reaction was carried out for $35 \mathrm{~min}$ at $90^{\circ} \mathrm{C}$ under constant stirring. The copolymer was purified by repeated precipitation into hexane, which was oven-dried at $40^{\circ} \mathrm{C}$ for $48 \mathrm{~h}$.

\section{RAFT polymerizations}

PMMA and PDMAEMA homopolymers and PMMA-coPDMAEMA were synthesized via RAFT technique using 2-cyano-2-propyl-dodecyl trithiocarbonate as the chain transfer agent (CTA), chosen considering the reactivity and compatibility with MMA and DMAEMA. The CTA used in all RAFT syntheses described herein is commonly used for polymerizing styrenes, methacrylates, and methacrylamides (17). The PDMAEMA synthesis was initiated using 1,1'-azobis(cyclohexanecarbonitrile) and all other reactions were initiated by azobisisobutyronitrile (AIBN). All syntheses were controlled with 2-cyano-2-propyl dodecyl trithiocarbonate as the CTA.
PDMAEMA $_{315}$. Initially, $100 \mathrm{~mL}(0.59 \mathrm{~mol} / \mathrm{L})$ of DMAEMA, followed by the addition of $0.2154 \mathrm{~g}(0.623$ $\mathrm{mmol} / \mathrm{L})$ of the CTA and $0.038 \mathrm{~g}(0.155 \mathrm{mmol} / \mathrm{L})$ of $\mathrm{ACHN}$ were mixed in the reaction flask. The reaction was carried out at $85^{\circ} \mathrm{C}$ for $5 \mathrm{~h}$. The homopolymer product was purified by repeated precipitation in hexane and, subsequently, dried in an oven for $48 \mathrm{~h}$ at $40^{\circ} \mathrm{C}$.

$P M M A_{60}$. Twenty milliliters $(0.19 \mathrm{mmol} / \mathrm{L})$ of MMA monomer was dissolved in $10 \mathrm{~mL}$ of 1,4-dioxane, followed by the addition of $0.45 \mathrm{~g}(1.30 \mathrm{mmo} / \mathrm{L})$ of CTA and 0.0355 $\mathrm{g}(0.21 \mathrm{mmol} / \mathrm{L})$ of AIBN. Synthesis was carried out under constant stirring for $5 \mathrm{~h}$ at $70^{\circ} \mathrm{C}$. Purification was performed by repeated precipitations in methanol. The resulting solid was dried in an oven for $48 \mathrm{~h}$ at $40^{\circ} \mathrm{C}$.

$P_{M M A_{31} \text {-Co-PDMAEMA }}$. Twenty milliters $(0.186$ $\mathrm{mol} / \mathrm{L})$ of MMA and $75 \mathrm{~mL}(0.444 \mathrm{mmol} / \mathrm{L})$ of DMAEMA monomer, free of polymerization stabilizer, $1.314 \mathrm{~g} \mathrm{(3.8}$ $\mathrm{mmol} / \mathrm{L})$ of CTA and $0.104 \mathrm{~g}(0.633 \mathrm{mmol} / \mathrm{L})$ of AIBN were mixed in a reaction flask under argon atmosphere for $3 \mathrm{~h}$ at $70^{\circ} \mathrm{C}$. GPC was used to monitor the synthesis progress. The reaction was stopped after the desired molecular weight $\left(M_{n}: 14,000 \mathrm{~g} / \mathrm{mol}\right)$ was reached. The final product was purified by repeated precipitations in hexane and subsequently dried at $40^{\circ} \mathrm{C}$ for $96 \mathrm{~h}$.

GPC. GPC was performed in a Shimadzu Prominence instrument (Japan) equipped with two Phenomenex (USA) columns (particle size: $5 \mu \mathrm{m}$, pore sizes: $10^{6} \AA$ and $10^{4} \AA$ ). The injected sample volume $(10 \mathrm{mg} / \mathrm{mL})$ was $10 \mu \mathrm{L}$. Column temperature was kept at $35^{\circ} \mathrm{C}$. Detection was based on differential refractive index (RI) (Shimadzu RID-10A, Japan). The mobile phase was THF with $0.3 \%$ of TEA as eluent at a flow rate of $0.8 \mathrm{~mL} / \mathrm{min}$. The system was calibrated with PMMA standards $\left(M_{n} \sim\right.$ $800-2,000,000 \mathrm{~g} / \mathrm{mol}$ ) (Figure 2).

\section{Nuclear magnetic resonance (NMR) spectroscopy}

One dimensional ${ }^{1} \mathrm{H}-\mathrm{NMR}$ spectra were recorded at room temperature on a Varian $300 \mathrm{MHz}$ NMR spectrometer (USA). NMR samples consisted of $10 \mathrm{mg}$ of polymer 


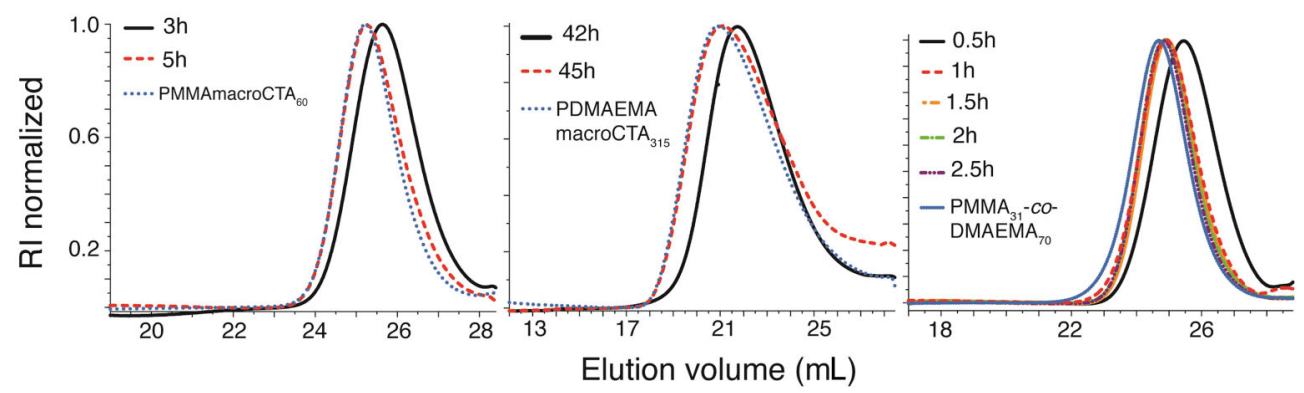

Figure 2. Polymer growth with synthesis time. Gel permeation chromatography traces showing the growth of homopolymer and

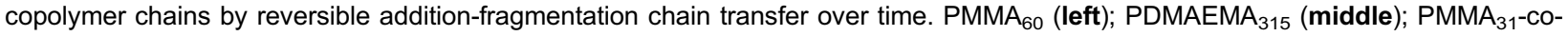
PDMAEMA $_{70}$ (right). The time course of the reaction is within each panel. RI: refractive index.

dissolved in $\mathrm{CDCl}_{3}$. PMMA and PDMAEMA ${ }^{1} \mathrm{H}$ chemical shift assignments were taken from the literature (18-21). PDMAEMA and PMMA ratios in the different copolymers $(\mathrm{n} / \mathrm{m}$ ratios) were calculated from the relative areas under the ${ }^{1} \mathrm{H}$ NMR peaks corresponding to the side chain methylene group of the ester of PDMAEMA at approximately $4.0 \mathrm{ppm}\left(2 \mathrm{H}, \mathrm{O}-\mathrm{CH}_{2^{-}}\right.$, PDMAEMA, see Figure 3) and to the ester methyl group of MMA at approximately 3.6 ppm (3H, O- $\left.\mathrm{CH}_{3}, \mathrm{PMMA}\right)$, according to Equation 1:

$$
\frac{\mathrm{n}_{(\mathrm{PDMAEMA})}}{\mathrm{m}_{(\mathrm{PMMA})}}=\frac{\mathrm{A}_{\mathrm{d}} \times 3}{\mathrm{~A}_{\mathrm{c}} \times 2}
$$

where $A_{d}$ and $A_{c}$ refer to the area under the peak of the PDMAEMA methylene group and the PMMA methyl group, respectively. The coefficients 2 and 3 normalize the areas with respect to the number of hydrogen nuclei contributing to each NMR signal, while $n$ and $m$ are the number of units of DMAEMA and MMA, respectively. The total polymer mass, $M_{n}$, is given by the relative composition of the two monomers as described in Equation 2:

$$
\mathrm{M}_{\mathrm{n}}=\mathrm{n} *(\mathrm{PDMAEMA})+\mathrm{m} *(\mathrm{PMMA})
$$

where (PDMAEMA) and (PMMA) are the monomer molecular masses, i.e., 157.9 and 100 , respectively.

\section{Propagation and purification of pUC19}

Transformation of competent $E$. coli $\mathrm{DH} 5 \alpha$ was carried out following standard methods (22-25). Briefly, approximately $50 \mathrm{ng}$ of pUC19 were mixed with $50 \mu \mathrm{L}$ of chemically competent $\mathrm{DH} 5 \alpha$ on ice for $30 \mathrm{~min}$. The mixture was subjected to heat shock at $42^{\circ} \mathrm{C}$ for $45 \mathrm{~s}$, incubated on ice for $1 \mathrm{~min}$, followed by the addition of $750 \mu \mathrm{L}$ of liquid sterile Luria broth (LB) (Sigma, USA) for cell growth at $37^{\circ} \mathrm{C}$ for $1 \mathrm{~h}$. Cells were harvested by centrifugation at $8,000 \mathrm{~g}$ for $5 \mathrm{~min}$ at room temperature, suspended with $100 \mu \mathrm{L}$ of LB, and plated on LB agar containing $100 \mu \mathrm{g} / \mathrm{mL}$ of ampicillin, $1 \mathrm{mmol} / \mathrm{L}$ of IPTG and $20 \mu \mathrm{g} / \mathrm{mL}$ of X-Gal. Bacterial cells were grown on plates overnight at $37^{\circ} \mathrm{C}$. On the next day, one colony of bacteria harboring pUC19 was selected based on the blue-white screening test and incubated in liquid LB under agitation at $230 \mathrm{rpm}$ and $37^{\circ} \mathrm{C}$ for overnight growth. pUC19 plasmids were isolated using the Plasmid Plus Maxi kit (Qiagen, USA) according to the manufacturer instructions $(26,27)$.

\section{Electrophoretic assays}

Agarose gel electrophoretic assays were performed using $1 \%$ agarose gels in TAE (Tris-Acetate-EDTA) buffer prepared with $6 \mu \mathrm{L}$ of SYBR Safe (Invitrogen, USA). The desired aliquots $(30,50$, and $100 \mu \mathrm{L})$ of a stock solution of each copolymer ( $1 \mathrm{mg} / \mathrm{mL}$ in THF) were transferred to plastic microtubes, and the solvent was evaporated under argon to allow the formation of polymeric films. A volume of $18 \mu \mathrm{L}$ of a water solution of pUC19 DNA at a concentration of $78 \mathrm{ng} / \mu \mathrm{L}$ (determined based on the absorbance at $260 \mathrm{~nm}$ ) was added, followed by vortexing for $10 \mathrm{~s}$, and resting on ice for $5 \mathrm{~min}$. An aliquot of $6 \mu \mathrm{L}$ of DNA loading buffer (Purple 6x) (Biolabs, Inc., USA) was added to each tube, which was again vortexed for $10 \mathrm{~s}$. All samples were maintained on ice in order to preserve the DNA from degradation. Electrophoresis was run in TAE buffer using 50 volts.

\section{Transformation of $E$. coli with polymer/pDNA polyplexes}

In order to verify the influence of the amount of each polymer on the bacteria transformation efficiency, desired aliquots $(0.25,0.5,1.0$, and $5.0 \mu \mathrm{L})$ of polymers taken from a $1 \mathrm{mg} / \mathrm{mL}$ stock in THF were transferred to plastic microtubes, followed by evaporation of the THF under argon until the formation of a film. Non-competent $E$. coli $\mathrm{DH} 5 \alpha$ cells were cultured in $100 \mathrm{~mL}$ of LB (Sigma) without antibiotics until the absorbance reached $0.7(\lambda=600 \mathrm{~nm})$. Cells were harvested by centrifugation $(8,000 \mathrm{~g}$, for $5 \mathrm{~min}$ at $4^{\circ} \mathrm{C}$ ), suspended into $500 \mu \mathrm{L}$ of $10 \mathrm{mM}$ MOPS pH 6.8, and reserved on ice. An aliquot of $10 \mu \mathrm{L}$ of a $78.7 \mathrm{ng} / \mu \mathrm{L}$ of pUC19 DNA solution in water was added to hydrate the polymeric film in the plastic microtube, followed by vigorous vortexing for one minute. After vortexing, the mixture rested for $5 \mathrm{~min}$ at $37^{\circ} \mathrm{C}$. A volume of $700 \mu \mathrm{L}$ of $\mathrm{LB}$ 

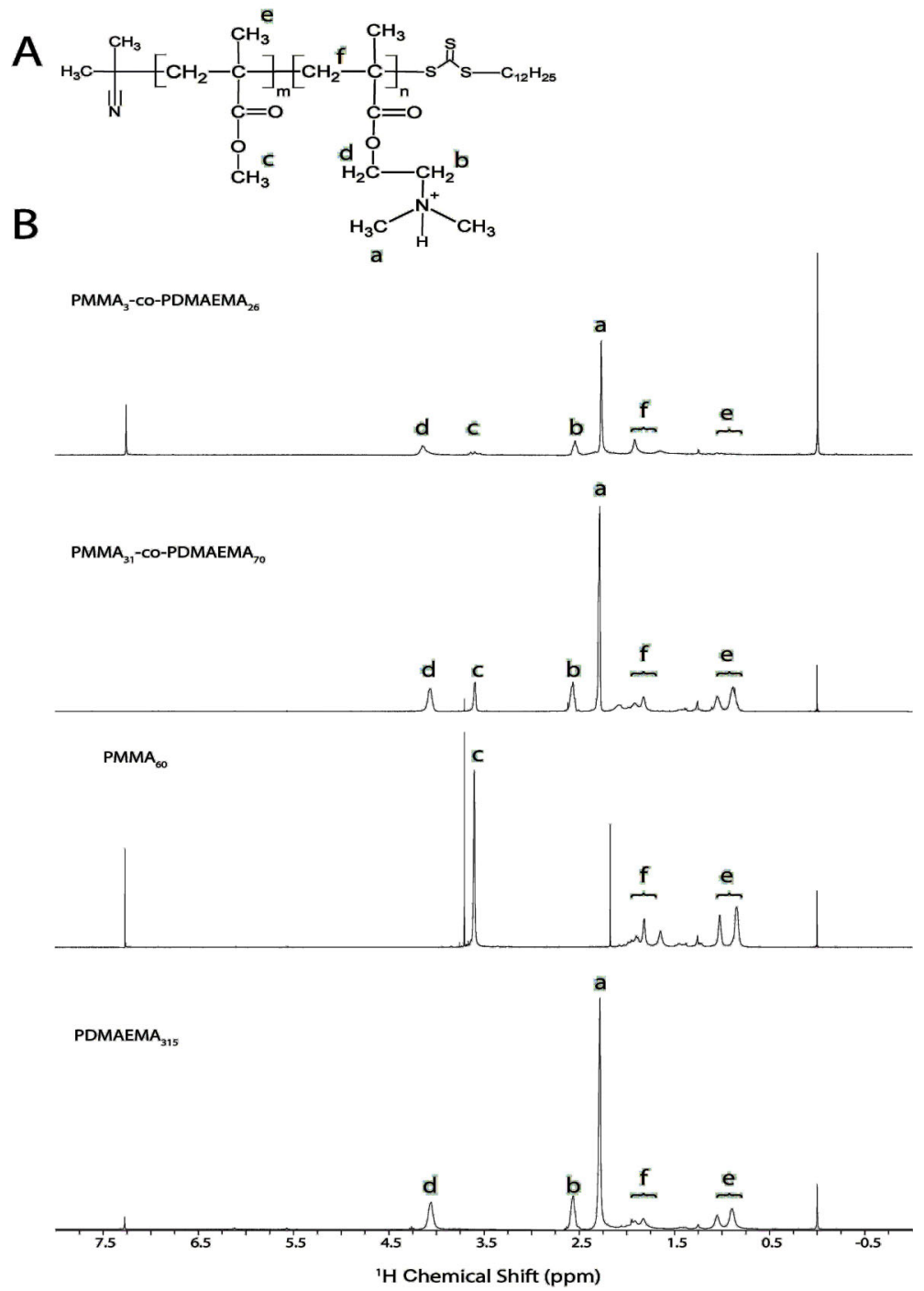

Figure 3. Structure and nuclear magnetic resonance (NMR) spectra of the polymers. General chemical structures $(\mathbf{A})$ and $\left({ }^{1} \mathrm{H}\right) \mathrm{NMR}$ spectra (B) of PMMA-co-PDMAEMA copolymers. The letters " $m$ " and " $n$ " refer to the number of MMA and DMAEMA units, respectively. All reversible addition-fragmentation chain transfer copolymers are expected to have chain-transfer agent terminations. The $\left({ }^{1} \mathrm{H}\right)$ NMR peaks at 4.05 and 3.60 ppm correspond to the $\left(\mathrm{O}_{-}-\mathrm{CH}_{2}-\right)$ of DMAEMA and the $\left(\mathrm{O}-\mathrm{CH}_{3}\right)$ of MMA, respectively.

was added to the hydrated polymeric film, followed by the addition of $100 \mu \mathrm{L}$ of non-competent $\mathrm{DH} 5 \alpha$ prepared as mentioned above, vortexed for $1 \mathrm{~min}$, and incubated at $37^{\circ} \mathrm{C}$ for $1 \mathrm{~h}$. A volume of $50 \mu \mathrm{L}$ of $\mathrm{DH} 5 \alpha$ cells incubated with polymer and pUC19 (49 $\mathrm{ng}$ ) were plated on LB-agar prepared with $100 \mu \mathrm{g} / \mathrm{mL}$ of ampicillin, $20 \mu \mathrm{g} / \mathrm{mL}$ of X-Gal, and $1 \mathrm{mmol} / \mathrm{L}$ of IPTG, and incubated at $37^{\circ} \mathrm{C}$ for $36 \mathrm{~h}$.

\section{Results and Discussion}

Although PDMAEMA homopolymers bind to DNA $(28,29)$, PDMAEMA-mediated DNA transfer to bacterial cells has not been reported. PDMAEMA binding to DNA results from electrostatic interactions but bacterial transfection may depend on the hydrophobic/hydrophilic balance of the polymeric material. To test whether increasing hydrophobicity could raise the ability of the polymer to mediate DNA transfer into bacterial cells, we designed amphipathic copolymers of different sizes and compositions. Homopolymers of PMMA, PDMAEMA, and copolymers containing DMAEMA/MMA units were synthesized to determine the impact of the different DMAEMA/MMA ratios on bacterial transformation efficiency. MMA was chosen as the hydrophobic component because it has been used to synthesize biocompatible materials for a wide variety of applications $(30,31)$. 
PMMA-co-PDMAEMA copolymers were synthesized either via free radical polymerization or via RAFT (see Methods), while PDMAEMA and PMMA homopolymers were synthesized via RAFT. Figure 2 shows GPC traces for all materials produced by RAFT. For this type of polymerization, average molar mass $\left(M_{n}\right)$ increase with conversion is expected (17). Average molar mass growth is detected by the displacement of the elution peak to lower volumes as a function of reaction time (32). After reaching the desired molecular weight $\left(M_{w}\right)$, the reaction was stopped, and the final product was purified.

${ }^{1} \mathrm{H}-\mathrm{NMR}$ of all copolymers (Figure 3 ) agreed with the literature (33). The peaks attributed to the main chain

Table 1. Synthesis parameters and selected characterization data.

\begin{tabular}{|c|c|c|c|}
\hline Material & Method & $\mathrm{M}_{\mathrm{n}}(\mathrm{kg} / \mathrm{mol})$ & $\mathrm{M}_{\mathrm{w}} / \mathrm{M}_{\mathrm{n}}$ \\
\hline $\mathrm{PMMA}_{60}$ & RAFT & 12.4 & 1.3 \\
\hline PDMAEMA $_{315}$ & RAFT & 54.6 & 1.4 \\
\hline (a) $\mathrm{PMMA}_{3}$-Co-PDMAEMA 26 & FRP & 4.45 & 1.9 \\
\hline (b) $\mathrm{PMMA}_{31}$-co-PDMAEMA 70 & RAFT & 14.0 & 1.3 \\
\hline
\end{tabular}

$M_{n}$ and $M_{w} / M_{n}$ were measured by gel permeation chromatography. RAFT: reversible addition-fragmentation chain transfer; FRP: free radical polymerization. protons ("e" and "f", Figure 3) were within the 0.7-2.0 ppm range. Peaks assigned to the PDMAEMA units were at $2.30 \mathrm{ppm}$ ("a", $\mathrm{N}-\mathrm{CH}_{3}$ ), $2.58 \mathrm{ppm}$ ("b", $\mathrm{N}-\mathrm{CH}_{2}$ ), and 4.08 ppm ("d", $\mathrm{O}-\mathrm{CH}_{2}$ ), respectively. The peak at 3.60 ppm was assigned to the PMMA side chain protons ("c", $\mathrm{O}-\mathrm{CH}_{3}$ ). The composition of the synthesized products, determined by ${ }^{1} \mathrm{H}$ NMR (Figure 3 ) as described in Methods section, using the areas of the signals " $c$ " and " $d$ ", are presented in Table 1. As the total average molar masses were determined by GPC using PMMA standards, the molar mass units refer to PMMA molar mass / hydrodynamic ratio relationships. The polymers obtained by RAFT presented low polydispersity $\left(M_{w} / M_{n}\right)$ characteristic of this technique (Table 1) (17).

Agarose gel electrophoresis of pUC19 demonstrated that DMAEMA-containing copolymers bind to DNA (Figure 4). pUC19 is a high-copy standard cloning vector containing the coding sequence of the alpha fragment of betagalactosidase (lacZ). pUC19 electrophoretic migration in the agarose gel yielded two bands, one of them corresponding to circular DNA, migrating with an apparent size larger than $10 \mathrm{~kb}$, and supercoiled DNA that migrated with an apparent size near $2 \mathrm{~kb}$ (Figure 4). This behavior is consistent with uncut plasmid DNA. Addition of either PDMAEMA $_{315}$ or PMMA $_{3}$-Co-PDMAEMA 26 (FRP) and $\mathrm{PMMA}_{31}$-Co-PDMAEMA 70 led to altered pUC19 migration

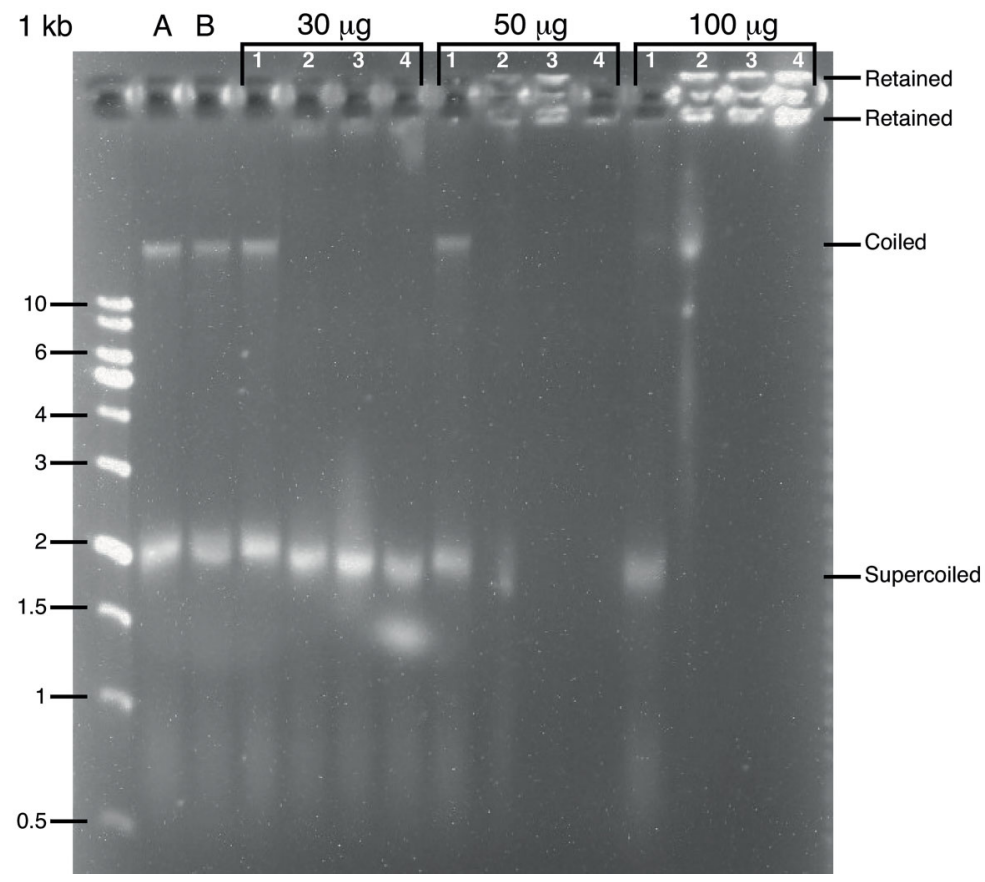

Figure 4. DNA polymer binding. Copolymer binding to $\mathrm{pUC1} 19$ shifts its migration band on agarose gel. The agarose gel electrophoresis was run for 90 min at 50 volts. The following amounts of copolymers were tested: 30,50 , and $100 \mu \mathrm{g}$. Lanes $A$ and B refer to controls corresponding to DNA only in the presence of tetrahydrofuran $(A)$ or buffer $(B)$ added in substitution of copolymer. The copolymers added in each experiment are indicated by numbers: $1=\mathrm{PMMA}_{60} ; 2=\mathrm{PDMAEMA}_{315} ; 3=\mathrm{PMMA}_{3}-\mathrm{CO}_{-} \mathrm{PDMAEMA}_{26}(\mathrm{FRP}) ; 4=\mathrm{PMMA}{ }_{31}{ }^{-}$ CO-PDMAEMA $_{70}$ 
and even retention of DNA near the application slot. $\mathrm{PMMA}_{60}$, on the other hand, did not affect pUC19 migration. These results confirmed the ability of PDMAEMA-containing polymers to bind to plasmid DNA. DNA binding is related to the presence of PDMAEMA, since methyl polymethacrylate $\left(P_{M M A_{60}}\right)$ at concentrations of 30 and $50 \mu \mathrm{g}$ did not affect DNA migration (Figure 4). Clearly, PDMAEMA monomers bearing a net positive charge are required for DNA binding and electrophoretic mobility shifts.

After observing that PDMAEMA-containing copolymers bind to plasmid DNA, we investigated whether these were able to mediate pUC19 delivery to non-competent E. coli cells, i.e., transfect. Bacterial colonies harboring pUC19 may be identified by the blue-white screening test. The expression of the lacZ fragment upon induction with IPTG results in a functional $\beta$-galactosidase that catalyzes

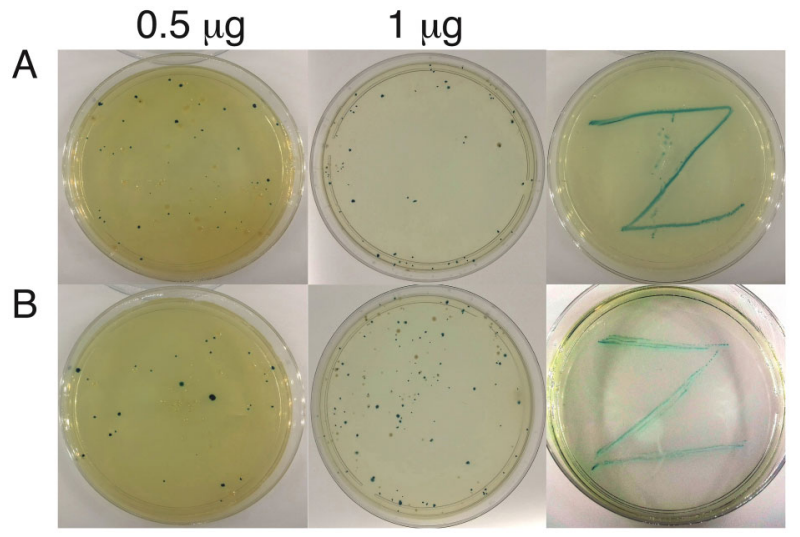

Figure 5. Demonstration of pUC19 transfection by polymers. Expression of pUC19 in E. coli $\mathrm{DH} 5 \alpha$ using the blue-white screening test. A, $\mathrm{PMMA}_{3}$-Co-PDMAEMA ${ }_{26}$ (FRP). B, PMMA ${ }_{31}$ co-PDMAEMA $A_{70}$. The amount of copolymer used in these experiments was $0.5 \mu \mathrm{g}$ (left plates) and $1 \mu \mathrm{g}$ (middle plates). The plates on the right refer to the inoculation of a single bluish colony, from the plates incubated with $1 \mu \mathrm{g}$ of polymer, in new agar plates containing IPTG and X-Gal. FRP: free radical polymerization. the cleavage of the glycosidic bond in the chromogenic substrate X-Gal added to the agar plates, yielding a blue pigment and hence blue colored colonies (34). Bacteria transformed with functional pUC19 were identified as blue colonies on agar plates (Figure 5). We found that only those $E$. coli cells that were incubated with pUC19 in the presence of $\mathrm{PMMA}_{3}$-co-PDMAEMA 26 (FRP) or $\mathrm{PMMA}_{31}$ Co-PDMAEMA ${ }_{70}$, but not in the presence of PDMAEMA $A_{315}$ or $\mathrm{PMMA}_{60}$ (not shown), yielded blue colored colonies in the agar plates. Controls performed in the absence of the polymer, which was substituted for THF or buffer, displayed no colonies (not shown). A single blue colony from the previous experiment was plated in a new LB-agar plate containing IPTG and X-Gal, yielding additional blue colonies after $12 \mathrm{~h}$ of incubation at $37^{\circ} \mathrm{C}$ (Figure 5). Therefore, the transformed colonies were fully functional, retaining the ability to grow and express the lacZ fragment.

$E$. coli cell growth was slower in the presence of copolymer. After transformation in the presence of copolymers, new colonies were visually observed on plates only after $36 \mathrm{~h}$ of incubation at $37^{\circ} \mathrm{C}$ instead of the usual growth time of $12 \mathrm{~h}$. In order to quantify the copolymer transformation efficiency, we counted the number of CFU (colony forming units) per microgram of DNA (Table 2). Copolymer transformation efficiency was in the range of $10^{3} \mathrm{CFU} / \mu \mathrm{g}$ of plasmid DNA and depended on the amount of copolymer used. The best copolymer amount was $0.5 \mu \mathrm{g}$ under our conditions (Table 2). We did not observe blue colonies when $E$. coli was transfected in the presence of $\mathrm{PMMA}_{60}$, in line with the observation that this polymer does not bind to DNA (Figure 4). Interestingly, PDMAEMA $A_{315}$ homopolymer also failed to transform $E$. coli even though it binds to DNA (Figure 4). The observed transformation efficiency, in the range of $10^{3} \mathrm{CFU} / \mu \mathrm{g}$ of plasmid DNA (Table 2 ), was lower than that usually obtained with chemically competent $E$. coli cells using calcium chloride (approximately 5-20 $\left.10^{6} \mathrm{CFU} / \mu \mathrm{g}\right)$. However, various factors may affect transformation efficiency, including the amount of viable cells. The number of colonies obtained displayed large variation between different transformation trials (Table 2).

Table 2. Escherichia coli transformation efficiency $\left(10^{3} \mathrm{CFU} / \mu \mathrm{g}\right.$ of DNA).

\begin{tabular}{|c|c|c|c|c|}
\hline \multirow[t]{2}{*}{ Polymer } & \multicolumn{4}{|c|}{ Transformation efficiency ${ }^{a}$} \\
\hline & $0.25 \mu \mathrm{g}^{\mathrm{b}}$ & $0.5 \mu \mathrm{g}^{\mathrm{b}}$ & $1 \mu g^{b}$ & $5 \mu g^{b}$ \\
\hline PDMAEMA $_{315}$ & 0 & 0 & 0 & 0 \\
\hline $\mathrm{PMMA}_{60}$ & 0 & 0 & 0 & 0 \\
\hline $\mathrm{PMMA}_{3}$-Co-PDMAEMA ${ }_{26}$ (FRP) & $0.20 \pm 0.04$ & $1.08 \pm 0.09$ & $0.63 \pm 0.52$ & $0.02 \pm 0.01$ \\
\hline PMMA $_{31}$-co-PDMAEMA 70 (RAFT) & $0.08 \pm 0.08$ & $0.88 \pm 0.12$ & $0.98 \pm 0.47$ & 0 \\
\hline THF & 0 & 0 & 0 & 0 \\
\hline Buffer & 0 & 0 & 0 & 0 \\
\hline Heat shock ${ }^{a}$ & 0 & 0 & 0 & 0 \\
\hline
\end{tabular}

CFU: colony forming units; ${ }^{a}$ non-competent cells; ${ }^{b}$ amount of polymer added (from $1 \mathrm{mg} / \mathrm{mL}$ of tetrahydrofuran (THF) solution). Data are reported as means \pm SD of three experiments. 
Although this last observation may be seen as a disadvantage of the method, the present results should be seen as a proof of principle. The contributions of all variables remain to be investigated in the future. In fact, one should keep in mind that fine-tuning the morphology of the copolymers could result in more efficient transfecting agents.

The presence of a small fraction of PMMA in the polymer chains was necessary for transfection. Note that only one homo PDMAEMA was used and that polymer was obtained exclusively by RAFT. A systematic change of those parameters is still needed in order to determine if PDMAEMA is not able to transfer DNA to bacteria no matter the variables. The data in Table 2 also indicate that $\left[\mathrm{PMMA}_{3}\right.$-Co-PDMAEMA 26 (FRP)] obtained by FRP technique was more efficient to transform $E$. coli than the one obtained by RAFT $\left(\mathrm{PMMA}_{31}\right.$-Co-PDMAEMA $\left.\mathrm{A}_{70}\right)$. These two copolymers differ by total molar mass, composition, and method of synthesis. Each one of these variables may be responsible for the difference in DNA transfer capability, as well as a combination of all. Molar mass is related to the size of the polyplex formed by combination with DNA, as well as toxicity (14,35-37). Differential composition is related to the hydrophilic/hydrophobic balance, which can certainly be a major factor to the interaction of the polyplex with the bacteria membrane. Finally, RAFT polymers present a sulphur group in one or both chain ends that can affect the DNA transfer process and toxicity. FRP polymers, on the other hand, present compositional interchain heterogeneity, making it difficult to know which chains specifically are the best transfer agent, composition-wise. All these scenarios are to be addressed in the future. We demonstrated here that copolymers of PDMAEMA and PMMA transferred DNA into E. coli, opening an opportunity to obtain more efficient and less toxic materials by varying their polymeric structure.

Transfer of foreign DNA into bacterial cells usually involves the generation of competence by a chemical

\section{References}

1. Blanazs A, Armes SP, Ryan AJ. Self-assembled block copolymer aggregates: from micelles to vesicles and their biological applications. Macromol Rapid Commun 2009; 30: 267-277, doi: 10.1002/marc.200800713.

2. Hu X, Zhang Y, Xie Z, Jing X, Bellotti A, Gu Z. Stimuliresponsive polymersomes for biomedical applications. Biomacromolecules 2017; 18: 649-673, doi: 10.1021/acs. biomac.6b01704.

3. Agut W, Brûlet A, Schatz C, Taton D, Lecommandoux S. pH and temperature responsive polymeric micelles and polymersomes by self-assembly of poly2-(dimethylamino)ethyl methacrylate]-b-poly(glutamic acid) double hydrophilic block copolymers. Langmuir 2010; 26: 10546-10554, doi: 10.1021/la1005693.

4. Su Y, Dan M, Xiao X, Wang X, Zhang W. A new thermoresponsive block copolymer with tunable upper critical solution temperature and lower critical solution temperature treatment with $\mathrm{CaCl}_{2}$ followed by a heat shock perturbation (38). Alternatively, one may use electroporation, in which a strong and short electrical pulse is applied to perturb the lipid bilayer allowing for the penetration of charged molecules such as DNA (39). Although these techniques are well-established, the transformation of other prokaryotic cells such as Leptospira, a pathogenic bacterium of significant public health concern, or Xanthomonas, a phytopathogenic bacterium that infects economically relevant crops, is not straightforward. Hence, simpler and more efficient DNA delivery methods for prokaryotic organisms are desirable and will find applications under specific situations. Here, we showed that copolymers based on MMA and DMAEMA were able to deliver foreign DNA into E. coli cells.

The mechanism of gene delivery promoted by the copolymers tested here is unclear. However, the composition of the polymeric material was determinant to gene delivery efficiency. Hydrophilic polymers containing only DMAEMA were unable to deliver DNA into $E$. coli (Figure 5 and Table 2). The presence of MMA units was found to be crucial for the cases studied. In summary, amphiphilic copolymers containing DMAEMA and MMA units were shown to deliver DNA into $E$. coli cells and might open the way for the development of new DNA delivery agents, which could find a variety of technological applications.

\section{Acknowledgements}

This research was funded by the São Paulo Research Foundation (FAPESP, grant numbers 2016/07490-1 and 2013/08166-5) and CNPq (grant numbers, 420490/2016-7 and 457733/2014-4). P.A.M. Vitale acknowledges a FAPESP PhD fellowship (2017/05614-8). V.V. de Souza acknowledges a CNPq PhD fellowship. I.M. Cuccovia and R.K. Salinas are CNPq research scholars.

in the alcohol/water mixture. J Polym Sci Part A: Polym Chem, 2013; 51: 4399-4412, doi: 10.1002/pola.26854.

5. Kocak G, Tuncer C, Bütün V. pH-responsive polymers. Polym Chem 2017; 8: 144-176, doi: 10.1039/C6PY01872F.

6. de Souza JCP, Naves AF, Florenzano FH. Specific thermoresponsiveness of PMMA-Block-PDMAEMA to selected ions and other factors in aqueous solution. Colloid Polym Sci 2012; 290: 1285-1291, doi: 10.1007/s00396-012-2651-9.

7. Ganta S, Devalapally H, Shahiwala A, Amiji M. A review of stimuli-responsive nanocarriers for drug and gene delivery. J Control Release 2008; 126: 187-204, doi: 10.1016/j. jconrel.2007.12.017.

8. Meng F, Zhong Z, Feijen J. Stimuli-responsive polymersomes for programmed drug delivery. Biomacromolecules 2009; 10: 197-209, doi: 10.1021/bm801127d.

9. Tanasienko IV, Yemets Al, Finiuk NS, Stoika RR, Blume YB. DMAEM-based cationic polymers as novel carriers for DNA 
delivery into cells. Cell Biol Int 2015; 39: 243-245, doi: 10.1002/cbin.10381.

10. Mahato M, Kumar P, Sharma AK. Amphiphilic polyethylenimine polymers mediate efficient delivery of DNA and SiRNA in mammalian cells. Mol Biosyst 2013; 9: 780-791, doi: 10.1039/c3mb25444e.

11. Cheng C, Convertine AJ, Stayton PS, Bryers JD. Multifunctional triblock copolymers for intracellular messenger RNA delivery. Biomaterials 2012; 33: 6868-6876, doi: 10.1016/j.biomaterials.2012.06.020.

12. Alhoranta AM, Lehtinen JK, Urtti AO, Butcher SJ, Aseyev VO, Tenhu HJ. Cationic amphiphilic star and linear block copolymers: synthesis, self-assembly, and in vitro gene transfection. Biomacromolecules 2011; 12: 3213-322, doi: 10.1021/bm2006906.

13. Bai YX, Liu YB, Li YF, Zhang Q. Synthesis and characterization of amphiphilic antibacterial copolymers. Polym Adv Technol 2012; 231; 581-587, doi: 10.1002/pat.1928.

14. Sprouse D, Reineke TM. Investigating the effects of block versus statistical glycopolycations containing primary and tertiary amines for plasmid DNA delivery. Biomacromolecules 2014; 15: 2616-2628, doi: 10.1021/bm5004527.

15. Deshpande MC, Garnett MC, Vamvakaki M, Bailey L, Armes SP, Stolnik S. Influence of polymer architecture on the structure of complexes formed by PEG-tertiary amine methacrylate copolymers and phosphorothioate oligonucleotide. J Control Release 2002; 81: 185-199, doi: 10.10 16/S0168-3659(02)00052-4.

16. Braunecker WA, Matyjaszewski K. Controlled/living radical polymerization: features, developments, and perspectives. Progress Polym Sci 2007; 32: 93-146, doi: 10.1016/j. progpolymsci.2006.11.002.

17. Perrier S. 50th Anniversary Perspective: RAFT Polymerization - A User Guide. Macromolecules 2017; 50: 7433-7447, doi: 10.1021/acs.macromol.7b00767.

18. Xiong Q, Ni P, Zhang F, Yu Z. Synthesis and characterization of 2-(dimethylamino)ethyl methacrylate homopolymers via aqueous RAFT polymerization and their application in miniemulsion polymerization. Polym Bull 2004; 53: 1-8, doi: 10.1007/s00289-004-0308-7.

19. Franco C, Antonow MB, Beckenkamp A, Buffon A, Ceolin T, Tebaldi ML, et al. Data of PCL-b-P(MMA-DMAEMA) characterization and related assays. Data Brief 2017; 15: 111-126, doi: 10.1016/j.dib.2017.09.010.

20. Sahnoun M, Charreyre MT, Veron L, Delair T, D'Agosto F. Synthetic and characterization aspects of dimethylaminoethyl methacrylate reversible addition fragmentation chain transfer (RAFT) polymerization. J Polym Sci 2005; 43: 3551-3565, doi: 10.1002/pola.20813.

21. Themistou E, Patrickios CS. Synthesis and characterization of amphiphilic star copolymers of 2-(dimethylamino)ethyl methacrylate and methyl methacrylate: effects of architecture and composition. Eur Polym J 2007; 43: 84-92, doi: 10.1016/ j.eurpolymj.2006.10.007.

22. Singh M, Yadav A, Ma X, Amoah E. Plasmid DNA transformation in Escherichia coli: effect of heat shock temperature, duration, and cold incubation of $\mathrm{CaCl}_{2}$ treated cells. Int J Biotechnol Biochem 2010; 6: 561-568.

23. Green R, Rogers EJ. Transformation of chemically competent E. coli. Methods Enzymol 2013; 529: 329-336, doi: 10.1016/B978-0-12-418687-3.00028-8.
24. Promega Corporation. E. coli Competent Cells Protocol Technical Bulletin., 2014, Available at https://www.promega. com.br/resources/protocols/technical-bulletins/0/e-coli-com petent-cells-protocol/.

25. Bergmans HE, van Die IM, Hoekstra WP. Transformation in Escherichia coli: stages in the process. J Bacteriol 1981; 146: 564-570, doi: 10.1128/JB.146.2.564-570.1981.

26. QIAGEN Plasmid Purification Handbook 06/2020, <www. qiagen.com $>$

27. Sambrook J, Russell DW (Editors). Molecular cloning: A laboratory manual. 2001, 3rd edition, New York: Cold Spring Harbor Laboratory Press; ISBN-10 0-87969-577-3; ISBN-13 978-0-87969-577-4.

28. Xue $Y$, Wei D, Zheng A, Guan $Y$, Xiao H. Study of stimulisensitivities of amphiphilic modified star poly [N, N-(dimethylamino) ethyl methacrylate] and its ability of DNA complexation. $J$ Macromol Sci Part A, Pure and Appl Chem 2014; 51: 898-906.

29. Arigita C, Zuidam NJ, Crommelin DJA, Hennink WE. Association and dissociation characteristic of polymer/DNA complexes used for gene delivery. Pharm Res 1999; 16: 1534-1541, doi: 10.1023/A:1015096302720.

30. Ali U, Karim KJBA, Buang NA. A review of the properties and applications of poly (methyl methacrylate) (PMMA). Polym Rev 2015; 55: 678-705, doi: 10.1080/15583724.2015.1031377.

31. Hollick EJ, Spalton DJ, Ursell PG, Pande MV. Biocompatibility of poly(methyl methacrylate), silicone, and AcrySof intraocular lenses: Randomized comparison of the cellular reaction on the anterior lens surface. J Cataract Refract Surg 1998; 24: 361-366, doi: 10.1016/S0886-3350(98)80324-6.

32. Neira-Velázquez MG, Rodríguez-Hernández MT, Hernández-Hernández E, Ruiz-Martínez ARY. Polymer molecular weight measurement. In: Handbook of polymer synthesis, characterization, and processing. Saldívar-Guerra E, Vivaldo-Lima E (Editors), Mexico: Wiley; 2013. p 355-366. ISBN: 978-0-470-63032-7.

33. Yang Y, Liu L, Zhang J, Li C, Zhao H. PMMA colloid particles stabilized by layered silicate with PMMA-b-PDMAEMA block copolymer brushes. Langmuir 2007; 23: 2867-2873, doi: 10.1021/la063078n

34. Zhang YS. Blue-white screening liquid can eliminate false positives in blue-white colony screening. Gene Mol Res 2016; 15: 1-8.

35. Cordeiro RA, Santo D, Farinha D, Serra A, Faneca H, Coelho JFJ. High transfection efficiency promoted by tailor-made cationic tri-block copolymer-based nanoparticles. Acta Biomater 2017; 47: 113-123, doi: 10.1016/j.actbio.2016.10.015.

36. Fischer D, Bieber T, Li Y, Elsässer HP, Kissel T. A novel nonviral vector for DNA delivery based on low molecular weight, branched polyethylenimine: effect of molecular weight on transfection efficiency and cytotoxicity. Pharm Res 1999; 16: 1273-1279, doi: 10.1023/A:1014861900478.

37. Islam MA, Park TE, Singh B, Maharjan S, Firdous J, Cho $\mathrm{MH}$, et al. Major degradable polycations as carriers for DNA and siRNA. J Control Release 2014; 193: 74-89, doi: 10.10 16/j.jconrel.2014.05.055.

38. Rahimzadeh M, Sadeghizadeh M, Najafi F, Arab S, Mobasheri H. Impact of heat shock step on bacterial transformation efficiency. Mol Biol Res Commun 2016; 5: 257-261, pISSN 2322-181X, elSSN 2345-22005.

39. Potter $\mathrm{H}$, Heller R. Transfection by electroporation. Curr Protoc Mol Biol 2018; 121: 9.3.1-9.3.13, doi: 10.1002/cpmb.48. 